\title{
Bambara groundnut/maize intercropping: Effects of planting densities in Southern guinea savanna of Nigeria
}

\author{
Godwin Adu Alhassan and Moses Onyilo Egbe* \\ Department of Crop Production, University of Agriculture, Makurdi, Nigeria. \\ Accepted 18 December, 2013
}

\begin{abstract}
A field experiment was conducted in 2010 and 2011 at the Teaching and Research Farm, Federal University of Agriculture, Makurdi, Nigeria. The aim was to determine the suitability of some landraces of bambara groundnut for intercropping at varying planting densities with maize. The experiment was a $2 \times 3 \times 3$ split-split plot laid in a randomized complete block design with three replications. Intercropping decreased number of pods and grain yields of bambara groundnut component. Number of pods and grain yields increased with increased planting density. Productivity indices indicated that bambara groundnut/maize intercropping was productive, and maize was the dominant component. The marginal rate of returns for the best combinations was $116.13 \%$, suggesting profitability of the intercropping systems.
\end{abstract}

Key words: Bambara groundnuts, maize, intercropping, planting density.

\section{INTRODUCTION}

Bambara groundnut [Vigna subterranean (L.) Verdc] occupies a peculiar position in the diet of the people of West Africa and some authors (Ocran, 1998; Mkandawire, 2007) have placed it as the third most important grain legume after groundnut and cowpea in the region. The annual world production of bambara groundnut is about 330,000 tonnes. A high percentage (45 to 50) of this is produced in West Africa. Nigeria is leading producer of bambara groundnut in the world, producing about 33,000 to 49,000 tonnes annually (PROTA, 2006). The crop is essentially grown for human consumption. Quedraogo et al. (2012) described bambara groundnut seed as a complete diet, making it a good supplement to cereal-based diets. Apart from the leaves that can be used for livestock feed (Massawe et al., 2002), bambara groundnut is grown primarily for its seeds, which are used in many types of food. Mature, dry seeds are boiled and eaten as a pulse. Dried seeds, either whole or split, are also mixed with maize or plantains and then boiled. The seeds may be ground into flour, spiced and steamed as "moimoi" or fried as "akara" (Kadams and Sajo, 1998; PROTA, 2006). The hardy nature of the crop and its drought tolerance may endear it for inclusion in climate change adaptation strategies.

Maize (Zea mays L.) is the most important cereal crop in the world after wheat and rice (Onwueme and Sinha, 1991). It is a major item in the diet of many tropical countries whereas in the temperate regions, maize is the main grain used for animal feed. In Nigeria, maize is consumed in many forms: as maize flour made into a thick paste ('tuwo') and eaten with soup, 'ogi' (pap) and 'agidi', boiled or roasted as fresh corn and eaten with or 
Table 1. Physical and chemical properties of the surface soil $(0$ to $30 \mathrm{~cm})$ at the experimental site in Makurdi in 2010 and 2011.

\begin{tabular}{|c|c|c|}
\hline \multirow{2}{*}{ Parameter } & \multicolumn{2}{|c|}{ Makurdi } \\
\hline & 2010 & 2011 \\
\hline Sand (\%) & 74 & 71 \\
\hline Silt (\%) & 18 & 18 \\
\hline Clay (\%) & 8 & 11 \\
\hline Textural class & Sandy loam & Sandy loam \\
\hline $\mathrm{pH}\left(\mathrm{H}_{2} \mathrm{O}\right)$ & 6.30 & 6.50 \\
\hline Organic carbon $\left(\mathrm{g} \mathrm{kg}^{-1}\right)$ & 8.82 & 6.62 \\
\hline Total $N\left(\mathrm{~g} \mathrm{~kg}^{-1}\right)$ & 0.70 & 1.00 \\
\hline Available $\mathrm{P}\left(\mathrm{cmol} \mathrm{kg}^{-1}\right.$ soil $)$ & 17.50 & 11.75 \\
\hline $\mathrm{Ca}^{2+}\left(\mathrm{cmol} \mathrm{kg}^{-1}\right.$ soil $)$ & 4.60 & 4.00 \\
\hline $\mathrm{Mg}^{2+}\left(\mathrm{cmol} \mathrm{kg}^{-1}\right.$ soil $)$ & 2.40 & 1.30 \\
\hline $\mathrm{K}^{+}\left(\mathrm{cmol} \mathrm{kg}^{-1}\right.$ soil $)$ & 0.14 & 0.12 \\
\hline $\mathrm{Na}^{+}\left(\mathrm{cmol} \mathrm{kg}^{-1}\right.$ soil $)$ & 0.65 & 0.78 \\
\hline ECEC (cmol kg ${ }^{-1}$ soil) & 7.79 & 6.20 \\
\hline
\end{tabular}

without groundnut, palm kernel, fried, etc. Maize is industrially important chiefly for the production of alcohol, oil and starch (Onwueme and Sinha, 1991).

Despite its vast potentials, bambara groundnut remains one of Africa's crops often neglected by science. Nigeria is believed to be one of the centres of origin of this crop, and possesses extensive bambara groundnut genetic resources (Tanimu and Aliyu, 1995). In Southern Guinea Savanna region of Nigeria, some of the popular landraces include, "Karo", "Okirikiri", "Adikpo","Kparuru", "Ikpeyiole" and "Carol". In this region, these landraces of bambara groundnut and some others are grown by subsistence farmers in small patches of land. It is regarded as women's crop in most cultures and frequently intercropped or mixed with cowpea, maize and sorghum (Mkandawire and Sibuga, 2002). One major constraint in bambara groundnut production in Southern Guinea Savanna is inadequate information on the type and intensity of mixtures with other crop types in the cropping systems practiced by farmers, although Ngugi (1995) had indicated that bambara groundnut would do well if intercropped with maize if the maize planting density was low. Planting density of bambara groundnut is often low ( $<100,000$ plants/ha) on farmers' fields (Egbe et al., 2009) resulting in low yields. Mkandawire and Sibuga (2002) had reported a spacing of $30 \times 30 \mathrm{~cm}$ (approximately 111,000 plants/ha) in Tanzania and $60 \times$ $30 \mathrm{~cm}(55,000$ plants/ha) in West Africa.

Research information on the optimal planting density of bambara groundnut when being intercropped with maize in Southern Guinea Savanna is lacking. There is also dearth of scientifically documented information on yield advantages and the profitability of the bambara groundnut/maize intercropping systems in Southern Guinea Savanna of Nigeria. The study reported here sought to fill this knowledge gaps.
The objective of the study was to investigate the suitability of some landraces of bambara groundnut for intercropping at different planting densities with maize in Makurdi, Nigeria.

\section{MATERIALS AND METHODS}

\section{Experimental site}

A field experiment was conducted for two years (2010 and 2011) at the Teaching and Research Farm of the Federal University of Agriculture, Makurdi (latitude $07^{\circ} 45^{\prime}$ to $07^{\circ} 50^{\prime} \mathrm{N}$, longtitude $08^{\circ} 45^{\prime \prime}$ to $08^{\circ} 50^{\prime} \mathrm{E}$, elevation $98 \mathrm{~m}$ above sea level, masl) in Benue State, located in the Southern Guinea Savanna of Nigeria. The experimental site received a total rainfall of 1115.3 and $1211.4 \mathrm{~mm}$ in 2010 and 2011, respectively. The soil was classified as Dystric Ustropept (USDA). The experiment was sited in the same location in each year.

\section{Soil sampling and analysis}

Ten core samples of soil were collected from different parts of the experimental field from a depth of 0 to $30 \mathrm{~cm}$ and bulked into a composite sample and used for the determination of the physical and chemical properties of the soil (Table 1) before planting.

\section{Experimental design, treatments and cultural practices}

The plot was manually cleared with machetes and ridged with hand hoes before laying the experiment as a $2 \times 3 \times 3$ split-split plot set out in a randomized complete block design with three replications. The main plot treatments were made up of two cropping systems [sole cropping (bambara groundnut), maize var. QPM] and intercropping (bambara groundnut + maize), while the sub-plot treatments were three bambara groundnut landraces ("Karo" "Okirikiri" and "Adikpo",). The sub-sub-plot treatments comprised of three planting densities of bambara groundnut $(200,000$ plants/ha, designated as $\mathrm{P} 1$ and set out as $1 \times 0.05 \mathrm{~m} \times 1$ plant/stand; 
100,000 plants/ha, designated as P2 and set out as $1 \times 0.1 \mathrm{~m} \times 1$ plant/stand; 50,000 plants/ha, designated as P3 and set out as $1 \times$ $0.2 \mathrm{~m} \times$ I plant/stand). The bambara groundnut landraces were obtained from the local markets in Ankpa ("Karo"), Otukpo ("Okirikri") and Makurdi ("Adikpo"). The maize variety used was var. QPM obtained from the Seed Technology Centre of University of Agriculture, Makurdi, Nigeria. The maize was planted in both sole and intercropping at 40,000 plants/ha, set out as $1 \times 0.25 \mathrm{~m} \times 1$ plant/stand. Intercropping was formed by planting bambara groundnut at the top of the ridge, while maize occupied the side of the same ridge in a 1:1 row arrangement. The gross plot was made up of four ridges, spaced $1 \mathrm{~m}$ apart and $3 \mathrm{~m}$ long $\left(12 \mathrm{~m}^{2}\right)$, while the net plot had two ridges, $2 \mathrm{~m}$ long $\left(4 \mathrm{~m}^{2}\right)$. Planting was done on the $5^{\text {th }}$ day of August in both years of the experiment. Each treatment plot received an equivalent of $300 \mathrm{~kg}$ of NPK: 15:15:15 fertilizer as basal dressing by broadcasting. The maize component was topdressed with Urea at $100 \mathrm{~kg} / \mathrm{ha}$ by side placement 6 weeks after planting (WAP). The experiment was weeded manually using small hand hoes at 3 and 6 WAP.

\section{Data collection and analysis}

The following data were collected:

(1) Bambara groundnut component: Number of pods per plant and seed yield $(\mathrm{t} / \mathrm{ha})$,

(2) Maize component: Dry shoot weight and grain yield (t/ha).

The productivity indices used to estimate the intercrop advantage were:

(a) Land equivalent ratio (LER), an accurate assessment of the biological efficiency of the intercropping situation (Ofori and Stern, 1987), was estimated as:

$\mathrm{LER}=(X a b / X a a)+(X b a / X b b)$

Where $X a a$ and $X b b$ are yields as sole crops of bambara groundnuts and maize and $X a b$ and $X b a$ are yields as intercrops of bambara groundnuts and maize. LER figures greater than 1 are considered advantageous.

b) Land equivalent coefficient (LEC), a measure of interaction concerned with the strength of relationship (Adetiloye et al., 1983) was calculated thus,

LEC $=$ PLER $a \times P$ LER $b$

Where, PLERa $=$ partial LER of bambara groundnuts and PLERb $=$ partial LER of maize. For a two-crop mixture the minimum expected productivity coefficient (PC) is $25 \%$, that is, a yield advantage is obtained if LEC value exceeds 0.25 .

(c) Putnam et al. (1984) had reported that relative species competition was often evaluated using Competitive ratio (CR), which is a measure of the times by which one component crop is more competitive than the other. CR was calculated thus:

$\mathrm{CR} a=\mathrm{PLER} a / \mathrm{PLER} b \times \mathrm{zba} / z a b$

Where CRa is the CR of bambara groundnut and PLERa and PLER $b$ are the LERs of bambara groundnut and maize respectively, zba is the proportion of bambara groundnut in the bambara groundnut/maize intercrop and zab is the proportion of maize in the bambara groundnut/maize intercrop. If $\mathrm{CR} a<1$, there is a positive benefit and the crop can be grown in association; if $\mathrm{CR} a>1$, there a negative benefit. The reverse is true for CR $b . \mathrm{d}$ ) Aggressivity as an index, represents a simple measure of how much the relative yield increase in crop ' $a$ ' is greater than that of crop ' $b$ ' in an intercropping system. It was computed as:

$\mathrm{AGGab}=(\mathrm{X} a b / \mathrm{XaaZab})-(\mathrm{Xba} X b b Z b a)$

Where, AGGab is aggressivity index, $\mathrm{Xaa}$ and $\mathrm{X} b b$ are yields as sole crops of ' $a$ ' and ' $b$ ' and $X a b$ and Xba are yields as intercrops of ' $a$ ' and ' $b$ ', Zab and Zba are the sown proportions of ' $a$ ' and ' $b$ ', respectively. If $A G G a b=0$, both crops are equally competitive; if AGGab is positive, ' $a$ ' is dominant; if AGGab is negative, ' $a$ ' is the dominated crop (Ghosh et al., 2006).

(e) Profitability of the intercrop system was established by the results of net benefit analysis and marginal rate of return as described by CIMMYT (1988). These are indicators of monetary incomes accruing to the farmers from the intercrop system.

Year $\times$ treatment interactions were not significant, so data for both years were pooled together and analyzed. Data generated were analyzed using GENSTAT $13^{\text {th }}$ Edition. Means were separated by the use of the least significant difference (LSD) test at $5 \%$ probability level. T-test was also used where necessary for paired comparisons at $5 \%$ level of probability

\section{RESULTS}

The rainfall received within the experimental period was considered adequate for crop growth and development.

\section{Bambara groundnut component}

\section{Number of pods per plant}

The main effects of cropping systems and landraces were significant $(P \leq 0.05)$, all other treatment effects were not $(P \geq 0.05)$ on the number of pods per plant of bambara groundnut landraces intercropped with maize in Makurdi. Table 2 shows the main effects of cropping systems and landraces on the number of pods per plant of bambara groundnut intercropped with maize in Makurdi. The number of pods per plant of sole cropped bambara groundnut was significantly higher than the intercropped treatments. The number of pods per plant of "Okirikiri" (10.67) was significantly higher than "Karo" (5.94) and "Adikpo" (5.67).

\section{Grain yield}

All the treatments had significant effects $(P \leq 0.05)$ on the dry grain yield of bambara groundnut intercropped with maize in Makurdi. Table 3 presents the effects of cropping systems $\times$ landraces $\times$ density on seed yield of bambara groundnut intercropped with maize in Makurdi. Grain yields of bambara groundnuts varied from 0.34 to $0.66 \mathrm{t} / \mathrm{ha}$ in sole systems and 0.23 to $0.53 \mathrm{t} / \mathrm{ha}$ under intercropping. Intercropping significantly lowered grain yields of bambara groundnuts. The grain yields of bambara groundnut landraces significantly decreased with declined planting density under both cropping systems. The grain yield of "Adikpo" in both sole (0.53 $\mathrm{t} / \mathrm{ha}$ ) and intercropping systems (0.43 t/ha) was significantly higher than "Karo" and "Okirikiri". 
Table 2. Main effects of cropping systems (CRS) and landraces on the number of pods per plant of bambara groundnut intercropped with maize in Makurdi.

\begin{tabular}{lc}
\hline Cropping systems & Number of pods/plant \\
\hline Sole cropping & 8.85 \\
Intercropping & 6.00 \\
Mean & 7.42 \\
FLSD (0.05) & 1.24 \\
& \\
Landraces & \\
Karo & 5.94 \\
Okirikiri & 10.67 \\
Adikpo & 5.67 \\
Mean & 7.42 \\
FLSD (0.05) & 3.00 \\
\hline
\end{tabular}

Table 3. Effects of cropping systems (CRS) $\times$ landraces $(\mathrm{VAR}) \times$ density (POP) on seed yield (t/ha) of bambara groundnut intercropped with maize in Makurdi.

\begin{tabular}{lccccc}
\hline Cropping systems & Landraces & P1 & P2 & P3 & Mean \\
\hline Sole cropping & Karo & 0.54 & 0.44 & 0.34 & 0.44 \\
& Okirikiri & 0.55 & 0.43 & 0.36 & 0.44 \\
& Adikpo & 0.66 & 0.50 & 0.45 & 0.53 \\
Mean & & 0.58 & 0.45 & 0.38 & 0.47 \\
Intercropping & Karo & 0.37 & 0.28 & 0.25 & 0.30 \\
& Okirikiri & 0.51 & 0.24 & 0.23 & 0.32 \\
& Adikpo & 0.53 & 0.42 & 0.35 & 0.43 \\
Mean & & 0.47 & 0.31 & 0.27 & 0.35 \\
CV $(\%)$ & & & & & \\
CRS & 1.7 & & & & \\
CRS $\times$ VAR & 5.1 & & & & \\
CRS $\times$ VAR $\times$ POP & 5.2 & & & & \\
FLSD (0.05) & & & & & \\
CRS & 0.02 & & & & \\
VAR & 0.03 & & & & \\
POP & 0.01 & & & & \\
CRS $\times$ VAR & 0.03 & & & & \\
CRS $\times$ POP & 0.02 & & & & \\
VAR $\times$ POP & 0.03 & & & & \\
CRS $\times$ VAR $\times$ POP & 0.04 & & & &
\end{tabular}

\section{Maize component}

\section{Maize grain yield and dry shoot weight}

Sole maize gave higher grain and dry shoot yields than intercropped treatments (Table 4). However, grain yield of sole maize and those intercropped with "Okirikiri" at P1 and "Adikpo" at P3 were at par. Also, dry shoot weight of sole maize was only significantly higher than those of intercropped maize with "Karo" at P3 and "Adikpo" at P1 and P2. The highest intercrop grain yield was obtained by "Okirikiri" landrace at P1 (2.21 t/ha), while the lowest was by "Okirikiri" at P2 (0.85 t/ha).

Land equivalent ratio, land equivalent coefficient, competitive ratio and aggressivity of intercropped Bambara with maize in Makurdi

Table 5 presents the LER, LEC, CR and aggressivity 
Table 4. Dry shoot weight at harvest (t/ha) and grain weight (t/ha) of maize intercropped with landraces of bambara groundnut in Makurdi.

\begin{tabular}{lcc}
\hline Treatment & Grain yield & Dry shoot weight \\
\hline Sole maize & 2.83 & 16.40 \\
Maize in Karo at P1 & 1.46 & 12.58 \\
Maize in Karo at P2 & 1.73 & 16.29 \\
Maize in Karo at P3 & 1.42 & 14.40 \\
Maize in Okirikiri at P1 & 2.21 & 16.21 \\
Maize in Okirikiri at P2 & 0.85 & 15.65 \\
Maize in Okirikiri at P3 & 1.69 & 16.06 \\
Maize in Adikpo at P1 & 1.31 & 13.40 \\
Maize in Adikpo at P2 & 1.53 & 13.34 \\
Maize in Adikpo at P3 & 2.12 & 14.95 \\
Mean & 1.72 & 14.93 \\
CV (\%) & 32.30 & 6.30 \\
FLSD (0.05) & 0.95 & 1.60 \\
\hline
\end{tabular}

Table 5. Land equivalent ratio (LER), land equivalent coefficient (LEC), competitive ratio (CRa, CRb) and aggressivity (AGGa, AGGb) of bambara groundnut intercropped with maize in Makurdi.

\begin{tabular}{lcccccc}
\hline Treatment & LER & LEC & CRa & CRb & AGGa & AGGb \\
\hline Karo in maize at P1 & 1.20 & 0.35 & 0.26 & 18.70 & -3.34 & 3.34 \\
Karo in maize at P2 & 1.25 & 0.39 & 0.52 & 6.00 & -1.35 & 1.35 \\
Karo in maize at P3 & 1.26 & 0.38 & 0.38 & 2.07 & -0.54 & 0.54 \\
Okirikiri in maize at P1 & 1.69 & 0.71 & 0.23 & 21.30 & -4.42 & 4.42 \\
Okirikiri in maize at P2 & 1.22 & 0.37 & 0.14 & 6.99 & -1.18 & 1.18 \\
Okirikiri in maize at P3 & 1.25 & 0.39 & 0.28 & 1.42 & -0.34 & 0.34 \\
Adikpo in maize at P1 & 1.27 & 0.37 & 0.35 & 14.28 & -3.95 & 3.95 \\
Adikpo in maize at P2 & 1.38 & 0.45 & 0.78 & 3.86 & -1.88 & 1.88 \\
Adikpo in maize at P3 & 1.50 & 0.56 & 0.26 & 1.56 & -0.34 & 0.34 \\
Mean & & & & & & \\
FLSD (0.05) & 0.005 & 0.004 & 0.009 & 0.15 & 0.03 & 0.24 \\
Paired t-test (0.05) CRa vs CRb & & \multicolumn{7}{c}{$-3.17^{*}$} \\
\hline
\end{tabular}

$a=$ Bambara groundnut; $b=$ maize. * , significant at $5 \%$ level of probability.

values of bambara groundnuts intercropped with maize in Makurdi in 2010 and 2011. All intercrop treatments produced LER values above unity and LEC values beyond 0.25 . Okirikiri combined with maize at $\mathrm{P} 1$ had the highest LER and LEC figures of 1.69 and 0.71 , respectively. Karo at $\mathrm{P} 1$ produced the lowest LER figure (1.49). CRa was $<1$ in all the intercrop combinations, but $\mathrm{CRb}$ was $>1$. While the $\mathrm{CR}$ of maize $(\mathrm{CRb})$ decreased with decline in planting density of bambara groundnut, the $\mathrm{CR}$ of bambara groundnut ( $\mathrm{CRa})$ had erratic response. Aggressivity values of intercropped bambara groundnut landraces with maize were all negative, while the maize component of the intercropping had positive values.

\section{Economic analysis}

Total variable cost (TVC), gross returns (GM), net benefits, and dominance and marginal analyses

TVCs of intercropped treatments were significantly higher than sole crop (Table 6). Bambara groundnut landraces intercropped at P1 with maize had the highest TVC (N144, 421.00/ha), while intercropping at P3 gave the lowest TVC (N120, 796.00) (Table 6) with a mean of N131, 296.00/ha. Gross returns ranged from N223, 960.00/ha ("Okirikiri" at P3) to N330, 200.00/ha ("Okirikiri" at P1) (Figure 1) with a mean of N274, 097.78/ha. Gross returns decreased with decline in planting density of 
Table 6. TVCs and net benefits of sole and intercrop treatments of bambara groundnut with maize.

\begin{tabular}{lcccc}
\hline \multirow{2}{*}{ Treatment } & \multicolumn{2}{c}{ TVC (N/ha) } & \multicolumn{2}{c}{ Net benefits (N/ha) } \\
\cline { 2 - 6 } & Sole crop & Intercrop & Sole crop & Intercrop \\
\hline Karo at P1 & $87,500.00$ & $144,421.00$ & $52,900.00$ & $134,179.00$ \\
Karo at P2 & $71,750.00$ & $128,671.00$ & $42,650.00$ & $126,529.00$ \\
Karo at P3 & $63,875.00$ & $120,796.00$ & $24,525.00$ & $119,004.00$ \\
Okirikiri at P1 & $87,500.00$ & $144,421.00$ & $55,500.00$ & $185,779.00$ \\
Okirikiri at P2 & $71,750.00$ & $128,671.00$ & $40,050.00$ & $126,769.00$ \\
Okirikiri at P3 & $63,875.00$ & $120,796.00$ & $29,725.00$ & $103,164.00$ \\
Adikpo at P1 & $87,500.00$ & $144,421.00$ & $84,100.00$ & $165,899.00$ \\
Adikpo at P2 & $71,750.00$ & $128,671.00$ & $58,250.00$ & $167,489.00$ \\
Adikpo at P3 & $63,875.00$ & $120,796.00$ & $53,125.00$ & $156,404.00$ \\
Mean & $74,375.00$ & $131,296.00$ & $48,980.56$ & $142,801.18$ \\
Maize & 111,296 & - & $103,936.00$ & - \\
Paired t-test(0.05) Sole vs intercrop & \multicolumn{2}{c}{$4.17^{*}$} & \multicolumn{3}{c}{$15.85^{*}$} \\
\hline
\end{tabular}

${ }^{*}$, Significant at $5 \%$ level of probability.

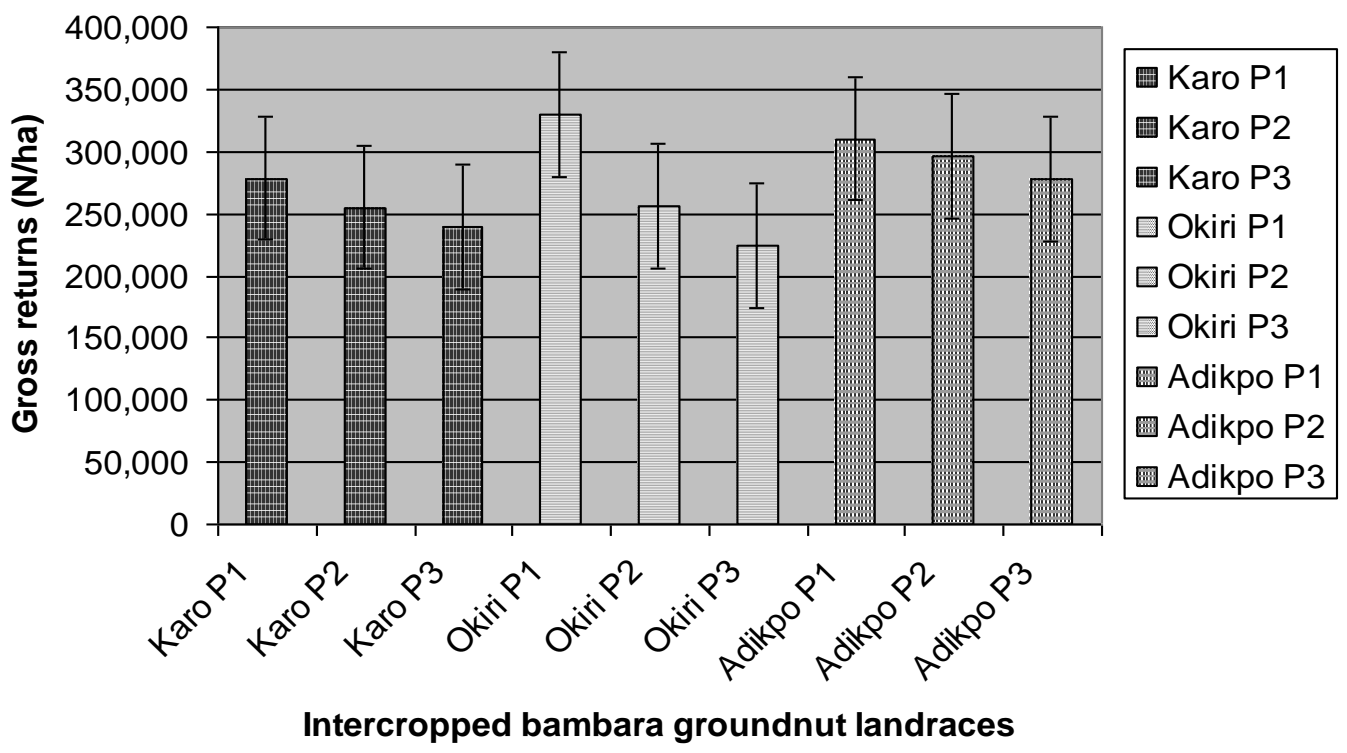

Figure 1. Gross returns of intercropped bambara groundnut landraces with maize at varying densities.

bambara groundnuts landraces (Figure 1). Net benefits of sole cropping were significantly lower than their intercrop counterparts (Table 6). Net benefits varied from N103, 164.00 (in "Okirikiri" at P3) to N185,779.00 ("Okirikiri" at $\mathrm{P1}$ ). All intercrop combinations with maize were dominated, except "Adikpo" at P3 and P2 and "Okirikiri at P1 (Table 7). The marginal rate of returns for the best two treatments was $116.13 \%$ (Table 8 ).

\section{DISCUSSION}

The reduction in the number of pods per plant and the grain yield of intercropped bambara groundnut landraces as compared to sole cropping could be ascribed to interspecies competition for both under- and above-ground growth resources (water, nutrients, light, air, etc.). The taller maize component shaded the low canopy legume, thus reducing light availability for optimum photosynthetic activity and subsequently culminating in the low yields of bambara groundnut. Such observations are common in legume/cereal intercropping (Molatudi and Mariga, 2012; Alhassan et al., 2013). The yield of bambara groundnut in this study was generally low ( 0.23 to $0.66 \mathrm{t} / \mathrm{ha}$ ) probably due to some inherent genetic properties/constraints, but Heuze' and Tran (2013) had reported average yields of 
Table 7. Dominance analysis of landraces of bambara groundnut intercropped at varying densities with maize in Makurdi, Nigeria.

\begin{tabular}{lccc}
\hline Treatment & TVCs (N/ha) & Net benefits (N/ha) & Remark \\
\hline Adikpo at P3 in maize & $120,796.00$ & $156,404.00$ & \\
Adikpo at P2 in maize & $128,671.00$ & $167,489.00$ & \\
Adikpo at P1 in maize & $144,421.00$ & $165,899.00$ & D \\
Okirikiri at P1 in maize & $144,421.00$ & $185,779.00$ & \\
Karo at P1 in maize & $144,421.00$ & $134,179.00$ & D \\
Okirikiri at P2 in maize & $128,671.00$ & $126,769.00$ & D \\
Karo at P2 in maize & $128,671.00$ & $126,529.00$ & D \\
Karo at P3 in maize & $120,796.00$ & $119,004.00$ & D \\
Okirikiri at P3 in maize & $120,796.00$ & $103,164.00$ & D \\
\hline
\end{tabular}

D, Dominated treatment.

Table 8. Marginal analysis of intercropped landraces of bambara groundnuts with maize at varying densities in Makurdi, Nigeria.

\begin{tabular}{lccccc}
\hline Treatment & TVCs & $\begin{array}{c}\text { Total marginal } \\
\text { costs }\end{array}$ & $\begin{array}{c}\text { Net } \\
\text { benefits }\end{array}$ & $\begin{array}{c}\text { Marginal net } \\
\text { benefits }\end{array}$ & $\begin{array}{c}\text { Marginal rate of } \\
\text { returns (\%) }\end{array}$ \\
\hline Adikpo at P3 in maize & $120,796.00$ & $7,875.00$ & $156,404.00$ & $11,085.00$ & 140.76 \\
& & & & & \\
Adikpo at P2 in maize & $128,671.00$ & \multirow{2}{*}{$15,750.00$} & $167,489.00$ & $18,290.00$ & 116.13 \\
Okirikiri at P1 in maize & $144,421.00$ & $185,779.00$ & & \\
\hline
\end{tabular}

300 to $800 \mathrm{~kg} / \mathrm{ha}$ and also indicated that yields of up to 4 $\mathrm{t} /$ ha was possible. The low yields reported here further points to the fact that more work on genetic improvement of these popular landraces and some others in the region should be intensified to improve the productivity of the crop to enhance food security in the face of current climate change. The decline in grain yields with decrease in planting density in both cropping systems tested suggested that increased yields from increased planting density beyond 200,000 plants/ha was possible. It further signifies that the optimum planting density for these bambara groundnut landraces is yet to be reached, opening windows for further studies. Kouassi and Zorobi (2011) had reported that higher yields were often associated with higher planting densities $(250,000$ plants/ha) of bambara groundnuts in Cote d'lvoire. Although yield depressions occurred, the maize component was more advantaged than the bambara groundnut. Trenbath (1976) had opined that the component of intercropping with its leaves held higher in the canopy structure was advantaged, particularly if the leaves were broad and horizontal. This was further proved by the positive aggressivity values of maize as compared to the negative values of the Bambara groundnut landraces. The positive aggressivity figures of maize showed that it was the dominant component of the intercropping, while bambara groundnut was dominated. Ghosh et al. (2006) stated that a positive aggressivity value meant dominance of a component crop in an intercrop arrangement. The $\mathrm{CR}$ figures of the bambara groundnut were significantly lower than those of maize, indicating superiority in competition by the maize component. Because adequate fertilizer was applied, maize plant height and biomass production were accelerated and subsequently its competitive abilities were enhanced. Egbe (2005) had observed similar results in pigeon pea/maize and pigeonpea/sorghum intercropping studies at Otobi and ascribed this superiority to height and biomass production advantage of the cereal component. The LER $(>1)$ and LEC $(>0.25)$ values obtained in this study proved that intercropping was advantageous. The intercrop advantage was due mainly to the greater grain yield of the maize component. Similar observations had been reported by Karikari (2003) in bambara groundnut intercropping with sorghum in Botswana. In this study, intercrop advantage was highest in Okirikiri at P1. This might be because maize combined with Okirikiri at $\mathrm{P} 1$ produced highest intercrop yield. Okirikiri combined with maize at P1 also produced the highest total gross returns and net benefits. Dominance analysis also showed that Okirikiri at P1 along with Adikpo at $\mathrm{P} 2$ and $\mathrm{P} 3$ were the only treatments not dominated. From the foregoing, Okirikiri at P1 proved to be one of the most suitable intercrop treatments in this study. Marginal analysis showed that intercropping Adikpo at P2 and P3 with maize and Okirikiri at P1 proved most profitable. Cropping systems strongly affected the net benefits derived from these intercrop combinations of bambara groundnuts and maize. The differences in yields, net benefits and marginal rate of 
returns of these landraces of bambara groundnuts under intercropping with maize further emphasizes the importance of evaluating crop varieties before making recommendations crop varieties for intercropping.

\section{REFERENCES}

Adetiloye PO, Ezedinma FOC, Okigbo BN (1983). A land coefficient concept for evaluation of competitive and productive interactions on simple complex mixtures. Ecol. Model. 19:27-39.

Alhassan GA, Kalu BA, Egbe OM (2013). Influence of planting densities on the performance of intercropped Bambara groundnut with cowpea in Makurdi,Benue State,Nigeria. Int. J. Dev. Sustain. 1(3) (in press).

CIMMYT (1988). An economic Training Manual: From Agronomic Data to Farmer Recommendation. CIMMYT, Mexico. pp. 11-14.

Egbe OM (2005). Evaluation of some agronomic potentials of pigeonpea genotypes for intercropping with maize and sorghum in Southern Guinea Savanna .Ph.D.thesis, University of Agriculture, Makurdi, Nigeria.

Egbe OM, Kalu BA, Idoga S (2009). Contribution of common food legumes to the fertility status of sandy soils of the Moist Savanna Woodland of Nigeria. Rep. Opin. J. 1(1):45-62.

Ghosh PK, Manna MC, Bandyopadhyay KK, Ajay, Tripathi AK, Wanjari RH, Hati KM, Misra AK, Acharya S, Rao CL (2006). Interspecific interaction and nutrient use in soybean/sorghum intercropping system. Agron. J. 98:1097-1108.

Heuze V, Tran G (2013). Bambara groundnut (Vigna subterranean) seeds. Feedipedia.org. A programme by INRA, CIRAD, AFZ and FAO. http//www.feedipedia.org/node/530. Last updated on July 1,2013,15:20.

Kadams AM, Sajo AA (1998). Variability and correlation studies in yield and yield components in bambara groundnut (Vigna subterranean (L.) Verdc). J. Appl. Sci. Manage. 2:66-70.

Karikari SK (2003). A decade of bambara groundnut agronomic research at the Botswana College of Agriculture. UNISWA J. Agric. 12:24-28.

Kouassi NJ, Zorobi IA (2011). Evaluation of agronomic performance of two landraces of Bambara groundnut (Vigna subterranea) in woodland savannahs of Cote d'Ivoire. Afr. J. Agric. Res. 6(2):48524856

Massawe FJ, Dickinson M, Roberts JA, Azam-Ali SN (2002). Genetic diversity in bambara ground nut (Vigna subterranean (L.) Verdc) land races revealed by AFLP Markers. Published on NRC Research press website at_htpp:/genome nrc ca. Canada.

Mkandawire $\mathrm{CH}$ (2007). Review of bambara groundnut production in sub-Saharan Africa. Agric. J. 2:464-470.
Mkandawire FL, Sibuga KP (2002). Yield response of bambara groundnut to plant population and seedbed type. Afr. Crop Sci. J. 10(1):39-49.

Molatudi RL, Mariga IK (2012). Grain yield and biomass response of a maize/dry bean intercrop to maize density and dry bean variety. Afr. J. Agric. Res. 7(20):3139-3146.

Ngugi GW (1995). Bambara Groundnut production in Kenya. In J. Heller, F. Begemann, J. Mushonga (Eds.), Bambara Groundnut Vigna Subterranea (L.) Verdc: Proceedings of the Workshop on Conservation and Improvement of Bambara Groundnut (Vigna Subterranea (L.) Verdc.): 14-16 November 1995, Harare, Zimbabwe Bioversity International, pp. 109-112.

Ocran VK (1998). Seed management manual for Ghana. Accra Ghana: MOFA

Ofori F, Stern WR (1987). Cereal-legume intercropping systems. Adv. Agron. 41:41-90.

Onwueme IC, Sinha TD (1991). Field crop production in tropical Africa CTA, Ede, the Netherlands. P. 480.

PROTA (Plant Resources of Tropical Africa) (2006). In Brink, M and G. Belay (eds). Cereals and Pulses, PROTA Foundation, Netherlands, pp. 213-217.

Quedraogo M, Zagre M'bi B, Jorgensen ST, Liu F (2012). Effect of mounding times on yield of bambara groundnut (Vigna subterranea (L.) Verdc.) landraces in Sahel-Burkina Faso. Afr. J. Agric. Res. 7(32):4505-4511.

Tanimu B, Aliyu L (1995). Country Report on Bambara groundnut production in Nigeria. In J. Heller, F. Begemann, and J. Mushonga (Eds.), Bambara Groundnut Vigna Subterranea (L.) Verdc: Proceedings of the Workshop on Conservation and Improvement of Bambara Groundnut (Vigna Subterranea (L.) Verdc.): 14-16 November 1995, Harare, Zimbabwe Bioversity International. pp. 8992.

Trenbath BP (1976). Plant interactions in mixed communities. In: Papendick, R. I., Sanchez, P. A. and Triplett, G. B. (Eds.). Multiple Cropping, ASA, CSSA and SSSA, Madison, WI, pp. 76-102. 